\title{
INTERNALISASI NILAI-NILAI KEISLAMAN TERHADAP PERKEMBANGAN ANAK DI SEKOLAH DASAR MUHAMMADIYAH KRIYAN JEPARA
}

\author{
Toni Ardi Rafsanjani, Muhammad Abdur Rozaq \\ Universitas Muhammadiyah Kudus \\ E-Mail: trfsanjani@yahoo.com
}

\begin{abstract}
This study aims to analyze and describe the internalization of Islamic religious education values on the students' development at Muhammadiyah Elementary School of Kriyan Jepara. This is qualitative research, taking the background of Muhammadiyah Elementary School of Kriyan Jepara. The data collection methods are indept interviews, participant observation and documentation. Data analysis is carried out by descriptive data analysis techniques which included three concurrent activities, data reduction, data presentation, and conclusion drawing. The results of this study are 1) Internalizing the values of Islamic religious education by planting theory / knowledge is strengthened by the word of Allah SWT and the hadith of the Prophet Muhammad;2) Internalization of the values of Islamic religious education is carried out with exemplary stories and wisdom of life; 3) Internalization of the values of Islamic religious education is carried out by learning religious and public materials that are interconnected through the synergy of the national education curriculum and Kemuhammadiyahan; 4) Internalization of the values of Islamic religious education is carried out through programs of intellectuality, spirituality and humanity. While the form of success is the habit of piety to shape students in to progressive students. The students carry out the internalization effort because trusting and adhering to it as a provision brings to mind peace and remembrance. Internalization effort is successfully carried out not because of a hard emphasis on education, but an effort to habituate the values of Islamic religious education that are religious humanists and carried out as often as possible, both in the school environment and at home.
\end{abstract}

Keywords: Internalization of PAI, Development of Students, Muhammadiyah Elementary school of Kriyan Jepara.

Abstrak: Penelitian ini bertujuan untuk menganalisis dan mendeskripsikan internalisasi nilai-nilai pendidikan agama Islam terhadap perkembangan anak di SD Muhammadiyah Kriyan Jepara. Penelitian ini adalah penelitian kualitatif, dengan mengambil latar SD Muhammadiyah Kriyan Jepara. Metode pengumpulan datanya adalah indept interviews, observasi partisipan dan dokumentasi. Analisis data dilakukan dengan teknik analisis data diskriptif yang mencakup tiga kegiatan bersamaan, reduksi data, penyajian data, dan penarikan kesimpulan. Hasil penelitian ini adalah 1) Internalisasi nilai-nilai pendidikan agama Islam dengan penanaman teoril ilmu yang dikuatkan dengan firman Allah SWT dan hadis Nabi Muhammad SAW; 2) Internalisasi nilai-nilai pendidikan agama Islam dilakukan dengan kisah-kisah teladan dan hikmah kehidupan; 3) Internalisasi nilai-nilai pendidikan agama Islam dilakukan dengan pembelajaran materi agama dan umum yang saling terkoneksi melalui sinergitas kurikulum pendidikan nasional dan Kemuhammadiyahan; 4) Internalisasi nilai-nilai pendidikan agama Islam dilakukan melalui program pembiasaan intelektualitas, spiritualitas dan humanitas. Sedangkan wujud keberhasilannya adalah pembiasaan kesalehan membentuk siswa menjadi pelajar 
yang berkemajuan. Para siswa melaksanakan upaya internalisasi itu karena memercayai dan menganutnya sebagai bekal membawa pada ketenangan pikir dan zikir. Upaya internalisasi berhasil dilakukan bukan karena penekanan pendidikan yang keras, melainkan usaha pembiasaan nilai-nilai pendidikan agama Islam yang humanis religius dan dilakukan sesering mungkin, baik di lingkungan sekolah maupun di rumah.

Kata Kunci: Internalisasi PAI, Perkembangan Siswa, SD Muhammadiyah Kriyan Jepara.

\section{PENDAHULUAN}

Pendidikan seacara kultural pada umumnya berada dalam lingkup peran, fungsi dan tujuan yang tidak berbeda. Semuanya hidup dalam upaya yang bermaksud mengangkat dan menegaskan martabat manusia melalui transmisi yang dimilikinya, terutama dalam rangka membentuk transfer of knowedge dan transfer of values. ${ }^{1}$

Dalam konteks ini secarajelas menjadi sasaran jangkauan pendidikan Islam, karena pendidikan Islam merupakan bagian dari sistem pendidikan nasional, sekalipun dalam kehidupan bangsa Indonesia tampak sekali terbedakan eksistensinya secara struktural. Sebagai pendidikan yang berlabel agama, maka pendidikan Islam memliliki transmisi spiritual yang lebih nyata dalam proses pengajarannya dibanding dengan pendidikan umum.

Dalam Undang-Undang No 20 Tahun 2003 tentang Sistem Pendidikan Nasional pasal 3 menyatakan bahwa Pendidikan Nasional berfungsi mengembangkan kemampuan dan membentuk watak serta peradaban bangsa yang bermartabat dalam rangka mencerdaskan kehidupan bangsa, bertujuan untuk mengembangkan potensi peserta didik agar menjadi manusia yang beriman dan bertakwa kepada Tuhan Yang Maha Esa, berakhlak mulia, sehat, berilmu, cakap, kreatif, mandiri, dan menjadi warga negara yang demokratis serta bertanggung jawab. ${ }^{2}$

1 Hasbullah, Kapita Selekta Pendidikan Islam, (Jakarta: PT Raja Grafindo Persada, 2004), hlm. 5.

2 Undang-Undang RI No. 20 Tahun 2003, Sistem

Pendidikan Nasional, (Bandung: Citra Umbara),
Pendidikan adalah pemindahan nilai-nilai, ilmu, dan keterampilan antara generasi tua dengan generasi muda untuk melanjutkan dan memelihara identitas masyarakat. ${ }^{3}$ Pendidikan sebagai usaha membina dan mengembangkan pribadi manusia pada aspek rohaniah dan jasmaniah harus berlangsung secara bertahap. Oleh karena itu, suatu kematangan yang bertitik akhir pada optimalisasi perkembangan dan pertumbuhan, baru dapat tercapai apabila berlangsung melalui proses demi proses ke arah tujuan akhir perkembangan dan pertumbuhan. ${ }^{4}$

Pendidikan merupakan proses belajar dan penyesuaian individu-individu secara terus menerus terhadap nilainilai budaya dan cita-cita masyarakat. Suatu proses pendidikan bangsa dalam menyiapkan generasi mudanya untuk menjalankan kehidupan dan memenuhi tujuan hidup secara efektif dan efesien. Kalau kita kembali pada pengertian pendidikan Islam, maka akan terlihat dengan jelas bahwa kemuliaan yang diharapkan dapat terwujud setelah orang mendapat pendidikan Islam, yaitu kepribadian seseorang yang membuatnya "insan kamil" dengan pola takwa. Insan kamil artinya manusia utuh rohani dan jasmani, dapat hidup dan berkembang secara wajar dan normal karena takwanya kepada Allah swt. ${ }^{5}$

hlm. 76.

3 Abudin Nata, 2000, Ilmu Pendidikan Islam, (Jakarta: PT Raja Grafindo Persada), hlm. 163.

4 Arifin Muzayyin, Filsafat Pendidikan Islam, (Jakarta: PT. Bumi Aksara, 2003), hlm. 12.

5 Zakiyah Daradjat, Ilmu Pendidikan Islam, (Jakarta: PT. 
Sebagaimana firman Allah dalam Q.S. Asy-Samsy: 7-10:

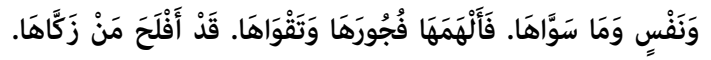

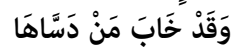
Artinya: "Demi jizwa dan penyempurnaan (ciptaannya), maka Allah mengilhamkan kepada jiwa itu (jalan) kefasikan dan ketakwaannya, sesungguhnya beruntunglah orang yang menyucikan jiwa itu, dan sesungguhnya merugilah orang yang mengotorinya". (QS. AsySyams [91]: 7-10).

Hal ini dapat dipahami bahwa tanpa melalui proses pendidikan, manusia dapat menjadi makhluk yang serba diliputi oleh dorongan-dorongan nafsu jahat, ingkar dan kafir terhadap Tuhannya. Hanya dengan melalui proses pendidikan, manusia akan dapat memanusiakan sebagai hamba Tuhan yang mampu menaati ajaran agamaNya dengan penyerahan diri secara total sesuai ucapan dalam salat.

Bagaimana pun pendidikan merupakan salah satu kunci yang sangat esensial dalam kehidupan manusia. Baik buruknya sumber daya manusia tergantung dari pendidikan yang diperolehnya. Pendidikan adalah sebuah investasi sumber daya manusia. Jika pendidikan yang diperoleh seseorang memiliki kualitas yang mumpuni, maka baik juga sumber daya manusianya. Maka dari itu, desain pendidikan selayaknya dipersiapkan secara matang sehingga hasil yang dicapai dapat memuaskan. ${ }^{6}$

Ki Hajar Dewantara menyatakan bahwa pendidikan adalah upaya untuk memajukan budi pekerti, pikiran dan jasmani anak-anak supaya selaras dengan alamdanmasyarakat. ${ }^{7}$ Dahulu, masyarakat

Bumi Aksara, 2006), hlm. 29.

6 Ahmad Syafi'i Ma'arif, Pendidikan Islam di Indonesia Antara Cita dan Fakta, (Yogyakarta: PT. Tiara Wacana, 1991), hlm. 15.

7 Ki Hajar Dewantara, Pendidikan, (Yogyakarta: Majelis Luhur Persatuan Taman Siswa, 1977), hlm. 14. menyangka bahwa mengajar sebenarnya tidak lebih dari memindahkan isi kepala seorang guru, kalaulah memang ilmu itu ada di kepala, kepada kepala seorang atau beberapa murid. Dengan demikian, terjadilah proses belajar. Dengan kata lain, bahwa belajar sebenarnya hanya memindahkan isi suatu keranjang kepada keranjang-keranjang yang lain.

Namun kemudian, kajian-kajian dalam psikologi, terutama dalam bidang proses belajar, menunjukkan bahwa memindahkan pengetahuan, apalagi nilai-nilai, dari seorang kepada orang lain, apalagi kalau dari satu generasi ke generasi berikutnya akan tampak tidak sederhana. Dalam proses belajar mengajar, pertama, seorang pelajar tidak hanya sekadar menerima dalam keadaan pasif, tetapi juga aktif dan dinamis, bahkan juga selektif dan mempunyai syaratsyarat tertentu, seperti ada rangsangan yang dilakukan oleh guru. Kedua ,adanya respons terhadap rangsangan tersebut. Ketiga, haruslah respons itu diteguhkan dalam bentuk ganjaran dan penghargaan lainnya. Untuk dapat memahami persyaratan proses belajar mengajar yang demikian itu, membutuhkan bantuan psikologi. ${ }^{8}$

Karena lembaga pendidikan merupakan aspek penting, maka perlu mengembangkan kurikulum berbasiskan internalisasikan nilai-nilai pendidikan Islam sejak dini dalam perkembangan anak. Oleh karena itu, Lembaga pendidikan Islam (sekolah) harus memberikan materi-materi yang Islami untuk mencetak generasi yang mampu mengamalkan Al-Qur'an dan sunah dalam kehidupannya.

Pendidikan agama Islam ialah usaha yang lebih khusus ditekankan untuk mengembangkan fitrah keberagaman (religiositas) subyek didik agar lebih mampu memahami, menghayati dan

$\overline{8} \quad$ Ibid., hlm. 164. 
mengamalkan ajaran-ajaran Islam. ${ }^{9}$ Marimba, sebagaimana dikutip oleh Tafsir, memberikan definisi bahwa pendidikan adalah bimbingan atau pimpinan secara sadar oleh pendidik terhadap perkembangan jasmani dan rohani anak didik menuju terbentuknya kepribadian yang utama. ${ }^{10}$

Pendidikan agama Islam merupakan pendidikan nilai, karena lebih banyak menonjolkan aspek nilai, yang patut untuk ditanamkan kepada peserta didik sehingga melekat pada dirinya, menjadi miliknya dan menyatu dengan jiwanya serta membentuk kepribadiannya. Pada proses pendidikan, dalam hal ini adalah penanaman nilai kepada peserta didik tentu tidak bisa lepas dari metode, karena metode proses pendidikan tidak akan dapat berlangsung secara efisien dan efektif dalam meraih tujuan. ${ }^{11}$

Pengertian tersebut sejalan dengan pengertian pendidikan agama Islam menurut perspektif kurikulum dan pembelajaran pendidikan agama Islam, yaitu upaya sadar dan terencana dalam menyiapkan peserta didik untuk mengenal, memahami menghayati hingga mengimani, bertaqwa dan berakhlak mulia dalam mengamalkan ajaran agama Islam dari sumber utamanya kitab AlQur'an dan hadis, melalui keteladanan, kegiatan bimbingan, pengajaran, latihan, serta penggunaan pengalamaan.

Sekolah merupakan aspek penting untuk pengembangan materi kurikulum berbasis nilai-nilai pendidikan Islam sejak dini dalam membentuk mental kepribadian yang berkemajuan. Karena itu, pendidikan agama Islam harus diinternalisasikan kepada peserta didik

9 Achmadi, Ideologi Pendidikan Islam, (Yogyakarta: Pustaka Pelajar, 2008), hlm. 29

10 Ahmad Tafsir. Ilmu Pendidikan dalam Perspektif Islam, (Bandung: PT. Remaja Rosdakarya, 2004), hlm. 24

11 H.M. Suyudi, Pendidikan dalam Perspektif Al Qur'an: Integrasi Epistemologi Bayani, Burhani dan Irfani, (Yogyakarta: Mikraj, 2005), hlm. 68. guna membentuk manusia yang utuh dan terampil.

Internalisasi nilai-nilai pendidikan merupakan salah satu cara untuk membentuk mental manusia agar memiliki kepribadian yang bermoral dan berbudi pekerti luhur. Internalisasi nilainilai pendidikan Islam berarti membentuk mental kepribadian anak dalam usia sejak dini. Diharapkan anak didik mampu tumbuh menjadi manusia yang konsisten dalam menjalankan syari'at agama Islam sehingga mampu membentuk mental yang berkemajuan di era yang serba modern.

SD Muhammadiyah Kriyan Jepara merupakan sekolah binaan Persyarikatan Muhammadiyah yang unggul dan mendapat kepercayaan masyarakat. SD Muhammadiyah Kriyan Jepara kerap menorehkan prestasi yang dapat membawa nama baik pendidikan Muhammadiyah, khususnya di Jepara. SD Muhammadiyah Kriyan Jepara memiliki Sumber Daya Manusia yang unggul dan berkarakter Islami. Budaya Islami yang diterapkan oleh guru dan siswa mampu meningkatkan budaya berkemajuan di lingkungan sekolah. Oleh sebab itu, animo masyarakat dalam menyekolahkan anak-anaknya ke SD Muhammadiyah Kriyan Jepara sangat tinggi. Untuk mencapai prestasi demikian memerlukan internalisasi pendidikan agama Islam agar terwujud pelajar yang berkemajuan.

\section{METODE PENELITIAN}

Paradigma penelitian ini termasuk penelitian kualitatif yang bersifat deskriptif. Jenis penelitian ini adalah penelitian lapangan (Field Research). Peneliti memilih SD Muhammadiyah Kriyan Jepara sebagai tempat (kancah) studi kasus. Objek dalam penelitian ini adalah di SD Muhammadiyah Kriyan Jepara. Subjek penelitian adalah orang atau masyarakat yang akan digali informasinya, seperti kepala sekolah, 
guru, karyawan, orang tua dan siswa SD Muhammadiyah Kriyan Jepara Tahun Pelajaran 2016-2017.

Pendekatan yang digunakan adalah pendekatan teologis/normatif. Penggunaan pendekatan teologis ini untuk mengaitkan data-data, fakta-fakta, informasi, dan tindakan (fenomena) tentang pelaksanaan pendidikan agama Islam dan internalisasi nilai-nilai Islami dalam pendidikan agama Islam pada proses belajar mengajar dengan dalil-dalil yang berkaitan dengan Allah.

Metode pengumpulan data yang dilakukan, meliputi wawancara, observasi dan dokumentasi. Peneliti menggunakan metode deskriptif kualitatif dalam menganilisis data. Metode deskriptif kualitatif mencakup reduksi data, kategorisasi data, sintesisasi dan diakhiri dengan menyusun interpretatif selanjutnya menarik kesimpulan.

\section{HASIL DAN PEMBAHASAN \\ Internalisasi Nilai-nilai Agama Islam}

Nilai adalah suatu perangkat keyakinan atau perasaan yang diyakini sebagai suatu identitas yang memberikan corak yang khusus kepada pola pemikiran, perasaan, keterkaitan maupun perilaku. Adapun nilai yang diyakini SD Muhammadiyah Kriyan Jepara termanifestasikan dalam ajaran agama Islam yang bersumber Al-Qur'an dan AlHadis.

Sedangkan internalisasi adalah suatu proses yang mendalam dalam menghayati nilai-nilai agama, dalam hal Islam yang dipadukan dengan proses pendidikan secara utuh, yang sasarannya menyatu dengan perkembangan kepribadian anak sehingga menjadi satu perilaku yang terpuji. SD Muhammadiyah Kriyan Jepara melakukan penanaman pendidikan karakter terhadap peserta didiknya dengan internalisasi keislaman dan kurikulum yang terpadu dengan kegiatan-kegiatan keagamaan sekolah.
Pada hakikatnya internalisasi adalah sebuah proses menanamkan sesuatu. Sedangkan ineternalisasi nilai-nilai agama adalah sebuah proses menanamkan nilai-nilai agama. Internalisasi ini dapat melalui pintu Institusional, yakni melalui pintu-pintu kelembagaan yang ada, misalnya lembaga Studi Islam dan lain sebagainya. SD Muhammadiyah Kriyan Jepara menerapkan internalisasi nilai-nilai agama Islam melalui pendirian sekolah Muhammadiyah di bawah Kementerian Pendidikan Nasional.

Berdasarkan hasil Musyawarah Cabang (Muscab) Kalinyamatan periode muktamar ke-45, para peserta Muscab merekomendasikan agar PCM Kalinyamatan mempunyai wadah/ lembaga pendidikan formal setingkat Sekolah Dasar yang menampung warga Muhammadiyah. Dengan hasil rekomendasi itu, disusunlah program kerja secara detail rencana strategisnya. Dengan mengintensifkan koordinasi dan pertemuan secara fokus yang membahas pendirian SD Muhammadiyah, dengan dimotori oleh para aghniya dan tokoh Muhammadiyah seperti dr. H. Zakariya, H. Abdul Rochim, H. Sidiq Amrosidi, H. Asmachan, Rusdiyono, dll maka ditetapkanlah Pimpinan Ranting Muhammadiyah Kriyan yang akan menjadi tempat lokasi berdirinya. Dengan bermodal gedung MIM 1 Kriyan sebagai prasyarat pendiriannya. Setelah diverifikasi oleh Disdikpora Kabupaten Jepara yang diwakili oleh bapak Drs. Bunaji, akhirnya terbitlah SK pendirian SK SD Muhammadiyah Kriyan oleh Kepala Disdikpora Kabupaten Jepara Nomor: 421.2/00274 tanggal 20 Juni 2008.

Selanjutnya adalah pintu personal, yakni melalui pintu perorangan khususnya para pendidik maupun orang tua. SD Muhammadiyah Kriyan Jepara menerapkan internalisasi nilainilai agama Islam dengan dikelola dan diselenggarakan oleh guru-guru 
yang dipilih sekolah untuk diamanahi sebagai pendidik yang sanggup menanamkan nilai-nilai agama Islam. Adapun dalam pelaksanaannya, guruguru SD Muhammadiyah Kriyan Jepara mendapat dukungan sinergis dari ikatan wali murid Sekolah, khususnya warga Muhammadiyah, untuk menguatkan langkah internalisasi tersebut.

Setelah mengantongi izin secara legal formal, proses KBMdiSD Muhammadiyah Kriyan terus menjunjukkan perkembangan yang signifikan sehingga mampu menempati kepemilikan Sekolah secara mandiri dan sah. Kini masyarakat luas mengharapkan agar SD Muhammadiyah Kriyan Jepara mampu menjadi lembaga pendidikan yang dapat mencetak generasi penerus, generasi Muhammadiyah yang berkemajuan dengan berkomitmen menjalankan visi sekolah, yakni terwujudnya insan yang unggul, cerdas, berakhlaq mulia berlandaskan iman dan taqwa berwawasan global serta menanamkan pola dan sikap hidup sehari-hari dengan cara Islami berdasar al Qur'an dan sunah Rasulullah SAW sebagaimana yang dikembangkan oleh KH. Ahmad Dahlan.

Cara internalisasi juga dapat dilakukan melalui pintu material, yakni melalui pintu materi perkuliahan atau kurikulum melalui pendekatan material, tidak hanya terbatas pada mata pelajaran pendidikan Agama Islam, tetapi juga bisa melalui kegiatan-kegiatan agama yang terdapat di sekolah. Dalam penerapannya, SD Muhammadiyah Kriyan Jepara memasukkan mata pelajaran pendidikan agama Islam, rutinitas kegiatan keagamaan sekolah dan pendidikan Kemuhammadiyahan sebagai sebuah strategi untuk melancarkan kesuksesan internalisasi Sekolah.

Materi Pendidikan Agama Islam adalah satuan pendidikan agama yang diajarkan kepada siswa-siswa SD Muhammadiyah Kriyan Jepara sesuai dengan kaidah Majelis Dikdasmen Muhammadiyah, antara lain : Akidah Akhlak, Ibadah (ubudiyah dan muamalah), Al-Qur'an Hadis, Bahasa Arab dan Tarikh Islam. Sedangkan materi Kemuhammadiyahan diajarkan kepada murid kelas 1 - VI dengan guru yang kompeten di bidang tersebut dengan alokasi 1 jam pelajaran dalam 1 minggu yang dititikberatkan pada pendalaman keyakinan terhadap nilai-nilai keislaman, keorganisasian, amal usaha, dan meneladani jiwa pengorbanan tokoh pendahulu Muhammadiyah.

Pintu material selanjutnya adalah kegiatan-kegiatan rutin yang dilakukan sekolah untuk menanamkan nilai-nilai agama Islam. Rutinitas program kegiatan keagaman di SD Muhammadiyah Kriyan meliputi kegiatan umum dan kegiatan khusus. Yang dimaksud kegiatan umum adalah kegiatan ISMUBA yang diikuti siswa-siswi di luar kegiatan sekolah dalam rangka pendalaman dan pengayaan amteri ISMUBA, antara lain: Darul Arqom Ramadhan, perlombaan "ISMUBA di lingkungan sekolah, perlombaan yang diadakan oleh DEPAG, DIKNAS, Dikdasmen atau lembaga yang lain.

Sedangkan kegiatan khusus yang dimaksud adalah kegiatan yang lazim dilaksanakan dalam lingkungan sekolah sebagai upaya pendahuluan materi ISMUBA, antara lain: Darul Arqom, Latihan Dasar Kepemmpinan (LDK), Peringatan Hari Besar Islam (PHBI), sholat berjamaah, sholat dhuha, tanya jawab agama, Tadarus Al-Quran, kuliah tujuh menit, hafalan surat-surat pendek (Juz 'Amma), hafalan do'a sholat wajib dan sunnah, hafalan do'a harian, kegiatan ekstrakurikuler, tartil, mubaligh kecil, qiro'ah dan membiasakan menggunakan bahasa Arab dan Inggris.

Materi ilmu yang paling terpenting dalam pelaksanaan internalisasi tersebut adalah pelaksanaan pendidikan 
nilai ketuhanan yang bertujuan untuk menginternalisasikan nilai-nilai ketuhanan sehingga menjiwai nilai-nilai etik insani. Siswa SD Muhammadiyah Kriyan Jepara secara umum berkewajiban untuk melaksanakan tata nilai akademik dan keislaman sekolah dengan meletakkan nilai ketuhanan pada posisi yang paling tinggi. Selain itu, bunyi ikrar pelajar memosisikan nilai ketuhanan sebagai inti dari kehidupan. Nilai itulah yang harus sejak dini ditanamkan ke dalam diri seseorang anak melalui proses pendidikan nilai yang dimaksudkan sebagai upaya mengikat seorang anak dengan dasardasar keimanan dan syariat.

Upaya internalisasi nilai tersebut diupayakan melalui langkah-langkah yang sistematis, antara lain menyimak, tanggapan, pengorganisasian, karakteristik sehingga proses pendidikan agama Islam akan melibatkan ragam aspek perkembangan peserta didik, seperti kognitif, konatif, afektif, serta psikomotorik sebagai suatu keutuhan dalam konteks kehidupan yang berkemajuan. SD Muhammadiyah Kriyan Jepara menanamkan pendidikan agama Islam melalui kurikulum pendidikan yang menyatu dengan pengembangan karakter dalam proses pembelajaran yang mendidik karena karakter tidak bisa dibentuk dalam perilaku instan.

Sementara itu, tahapan internalisasi nilai diupayakan melalui tahap-tahapan yang berurutan dan sistematis, antara lain tahap transformasi nilai, tahap transaksi nilai, tahap trans-internalisasi yang mendorong upaya internalisasi sebagai sentral proses perubahan kepribadian yang merupakan dimensi kritis pada perolehan atau perubahan diri manusia, termasuk di dalamnya kepribadian makna (nilai) atau implikasi respons terhadap makna.

Internalisasi Pendidikan Agama Islam di SD Muhammadiyah Kriyan Jepara diupayakan melalui karakter keteladanan dari para pendidik dan segenap pengelola dan penyelenggara sekolah. Guru harus mampu menjadi teladan bagi para siswa, terutama dalam menunjukkan kedisiplinan bekerja dan beribadah. Kedisiplinan guru tersebut menjadi modal utama dalam mewujudkan internalisasi pendidikan agama Islam. Selanjutnya, setelah guru memberikan contoh dengan kedisiplinan beribadah dan bekerja, sekolah membuat tata tertib yang mengikat para siswa agar dapat menerapkan nilai-nilai agama Islam dengan penuh kesadaran dan tanggung jawab.

Untuk mendapatkan kesadaran dan rasatanggungjawabitu, makainternalisasi harus memiliki sasaran yang perlu dijadikan prioritas dalam internalisasi nilai-nilai agama Islam terhadap perkembangan anak, diantaranya yaitu meningkatkan dasar-dasar pengetahuan seorang muslim tentang pokok-pokok ajaran Islam, sehingga mereka menyadari dan menghayati kelengkapan Islam sebagai pegangan hidup, membiasakan anak melakukan praktek-praktek ibadah yang murni berdasarkan Al Qur'an dan Hadits, melatih anak untuk peka terhadap permasalahan di lingkungan sekitar dan selalu merasa terpanggil terhadap masalah-masalah sosial ummat, sehingga melaksanakan kebaikan dan mencegah kemungkaran.

SD Muhammadiyah Kriyan Jepara merumuskan dan menjalankan budaya karakter Islami untuk menyasar tujuantujuan yang diharapkan. Budaya karakter Islami mewujud di setiap waktu dan tempat, seperti di ruang publik, di rumah, di kelas, di lingkungan sekolah dan pada saat bermain sekalipun. Sebagai contoh, saat bermain para siswa SD Muhammadiyah Kriyan Jepara membiasakan untuk menjaga kesopanan, saling menghormati dan menyayangi baik kepada teman kelas, adik kelas atau kakak kelas serta bapak/ibu guru, tidak 
memperlihatkan kesombongan kepada siapapun, ketika menang dalam bermain tidak sombong, ketika kalah masih ada kesempatan untuk menang, berkata dengan baik dan santun.

Pada waktu di belajar di ruang kelas para siswa SD Muhammadiyah Kriyan Jepara melakukan kesalehankesalehan seperti menjaga ketertiban dan kebersihan kelas, mengikuti pelajaran dengan seksama dan focus pada pelajaran, mengerjakan tugas dari bapak/ibu guru, izin dengan berbahasa yang santun bila meninggalkan ruangan, dan tidak perlu mengajak teman, salam ketika masuk ke kelas, mengangkat tangan ketika mau bertanya, berdoa sebelum belajar dimulai dan sesudahnya, berkata yang baik saja atau lebih baik diam, melaksanakan petunjuk bapak/ibu guru, tidak diperkenankan membawa mainan, HP atau apapun yang mengganggu belajar.

Pada saat di rumah para siswa SD Muhammadiyah Kriyan Jepara melakukan kesalehan-kesalehan seperti menjaga diri untuk tetap berbuat yang terbaik, menjaga lisan untuk selalu bicara yang baik atau lebih baik diam, menjaga diri tetap belajar, ngaji dan sholat khusyuk secara berjamaah bersama orang tua di rumah atau di masjid, menjaga waktu emas (Mulai Maghrib sampai Isya') untuk menjalankan kewajiban berupa belajar, sholat dan ngaji dengan mematikan TV sementara, tidur tidak terlalu malam (Jam 08.00) bangun ketika Shubuh untuk segera ambil wudhu dan sholat shubuh.

Pada saat apel pagi para siswa SD Muhammadiyah Kriyan Jepara melakukan peraturan ketertiban seperti memulai kegiatan sekolah di pagi hari dengan saling berjabat tangan, anak apel dengan baris teratur dan rapi, membaca do'a pagi hari dan ikrar anak sholeh, anak menyiapkan barisan bapak/ibu guru ikut menata barisan yang belum tertib, kepala sekolah atau guru yang bertugas memimpin apel memberikan tausiyah
5 menit berupa wejangan, motivasi, atau menghafal hadits pendek, atau mengingatkan tata tertib sekolah dan lain-lain.

Pada saat di masjid untuk beribadah kepada Allah SWT., para siswa SD Muhammadiyah Kriyan Jepara melakukan kesalehan-kesalehan seperti membiasakan siswa sholat lima waktu, membudayakan sholat berjama'ah, melaksanakan sholat seperti sholatnya Rasulullah SAW., berdoa sebelum masuk masjid, menuju ke masjid dengan penuh khidmat, melepas sepatu, menatanya dengan rapi, masuk masjid dengan kaki kanan terlebih dahulu, memerhatikan adab wudhu,selalu berdzikir dan berdo'a.

Kesalehan-kesalehan di atas dilakukan dengan berturut-turut sebagai proses bimbingan, baik jasmani maupun rohani kepada peserta didik secara sadar dan terencana dalam rangka mengembangkan potensi fitrahnya menurut nilai-nilai ajaran Islam agar kelak dapat berguna menjadi pedoman hidupnya untuk mencapai kebahagiaan hidup serta berguna bagi bangsa dan agamanya. Pendidikan agama Islam dengan sandaran Islamnya sebagai agama, memiliki tujuan pendidikan yang sangat universal dan mendalam. Adapun tujuan pendidikan agama Islam itu adalah antara lain: untuk mendekatkan diri kepada Allah, yang wujudnya adalah kemampuan dan dengan kesadaran diri melaksanakan ibadah wajib dan sunnah; menggali dan mengembangkan potensi atau fitrah manusia; mewujudkan profesionalisasi manusia untuk mengemban tugas keduniaan dengan sebaik-baiknya; membentuk manusia yang berakhlak mulia, suci jiwanya dari kerendahan budi dan sifat-sifat tercela; mengembangkan sifat-sifat manusia yang utama sehingga menjadi manusia yang manusiawi.

Pendidikan Islam bertujuan menginformasikan, mentransformasikan 
serta menginternalisasikan nilai-nilai Islami. Dengan demikian pendidik diharapkan dapat menumbuhkan kesadaran dan mengembangkan segisegi kehidupan spiritual yang baik dan benar dalam rangka mewujudkan pribadi muslim seutuhnya dengan ciriciri beriman, taqwa, berbudi pekerti luhur, cerdas, terampil dan bertanggung jawab. Untuk mencapai tujuan tersebut diperlukan penyusunan strategi pendidikan yang terencana dan sistematis, antara lain menyusun materi-materi yang relevan dengan tingkat perkembangan dan kemampuan berfikir peserta didik serta menerapkan metode pembelajaran yang efektif dan efisien.

Menurut Abdullah Nashih Ulwan bahwa cara yang dilakukan untuk membina nilai-nilai keagamaan atau agama Islam pada anak/peserta didik dapat melalui beberapa metode, yaitu metode keteladanan, metode pembiasaan, metode nasihat, metode pengawasan, metode hukuman (sanksi). Adapun metode-motede tersebut dilakukan SD Muhammadiyah Kriyan Jepara untuk mengusahakan internalisasi nilai-nilai agama Islam terhadap perkembangan para siswa.

Internalisasi Pendidikan Agama Islam di SD Muhammadiyah Kriyan Jepara diupayakan melalui karakter keteladanan dari para pendidik dan segenap pengelola dan penyelenggara sekolah. Guru harus mampu menjadi teladan bagi para siswa, terutama dalam menunjukkan kedisiplinan bekerja dan beribadah. Kedisiplinan guru tersebut menjadi modal utama dalam mewujudkan internalisasi pendidikan agama Islam. Selanjutnya, setelah guru memberikan contoh dengan kedisiplinan beribadah dan bekerja, sekolah membuat tata tertib yang mengikat para siswa agar dapat menerapkan nilai-nilai agama Islam dengan penuh kesadaran dan tanggung jawab.
Nilai-nilai agama Islam ditanamkan kepada para siswa dengan teori/ilmu yang dikuatkan dengan firman Allah SWT dan hadis Nabi Muhammad SAW maupun dengan keteladanan dari berbagai pihak (sekolah, keluarga dan masyarakat). Internalisasi agama Islam mula-mula berawal dari pemahaman dan akhirnya harus dilaksanakan pada tahap pengamalan sehari-hari dalam kehidupan nyata dengan memberi pengertian kepada siswa kemudian guru memberikan contoh konkret dalam bertutur, bersikap dan bertindak. Pemberian contoh dilakukan oleh semua unsur yang ada di sekolah sehingga mempengaruhi siswa untuk selalu menerapkan nilai-nilai keislaman dan adanya kesesuaian teori dan praktik nyata agar mampu memantapkan keyakinan siswa untuk mengamalkan kesalehan.

Sedangkan dalam mengaplikasikan metode tersebut di atas, ada beberapa tahapan yang harus dilalui, yakn tahapan pemahaman, tahapan penyadaran, tahapan praktik (amaliah). Dari pemahaman akan muncul kesadaran dan kesadaran menjadi landasan dalam beramal. Tahapan ini merupakan hasil dari kedua tahapan sebelumnya. Dalam tahapan ini dapat menggunakan metode penugasan, maupun keteladanan.

Internalisasi nilai-nilai keislaman juga dilakukan dengan kisah-kisah teladan dan hikmah kehidupan selain dengan memberikan dalil-dalil AlQur'an dan hadis. Internalisasi nilai keislaman senantiasa dilakukan dengan pembelajaran-pembelajaran agama dan umum. Mata pelajaran Qur'an Hadis, Aqidah Akhlak, Fikih, Tarikh dan Studi Kemuhammadiyahan menjadi modal utama dalam penerapan internalisasi nilai keislaman. Sementara mata pelajaran umum, seperti Pendidikan Kewarganegaraan, Ilmu Pengetahuan Sosial, Ilmu Pengetahuan Alam dan lain-lain turut menjadi penguat untuk 
memantapkan kesalehan siswa.

Rutinitas kegiatan pembelajaran di SD Muhamamdiyah Kriyan Jepara didukung dengan berbagai program pembiasaan keagamaan dan moral untuk para siswa dan guru, seperti tadarus pagi, salat dhuha (sunah) dan salat wajib secara berjamaah, menjaga kebersihan, pembiasaan 5 S (Senyum, Salam, Sapa, Sopan dan Santun) dan berjabat tangan saat bertemu, menegakkan kejujuran, menjunjung perilaku antre, menghormati guru dan menyayangi teman.

Program pembiasaan tersebut senantiasa diikuti dengan pengawasan dan pemberian nasihat dan dialog kepada siswa secara terus-menerus. Pemberian nasihat dan pendekatan dengan dialog dilakukan ketika ada siswa yang tidak menaati peraturan. Selain dengan strategi pembiasaan, proses internalisasi nilai pendidikan agama Islam terhadap perkembangan siswa dilakukan dengan strategi pembelajaran berupa metode ceramah, metode praktik, metode pemberian tugas dan pendampingan secara langsung.

Bentuk-bentuk nilai yang diajarkan di SD Muhammadiyah Kriyan Jepara adalah kejujuran, keadilan, toleransi, kebijaksanaan, disiplin diri, tolong menolong, peduli sesama, kerja sama, keberanian, dan sikap demokratis. Nilainilai tersebut merupakan bentuk dari rasa hormat dan atau tanggung jawab yang ditekankan di lingkungan keluarga, sekolah dan masyarakat.

Siswa berprestasi dan teladan dalam pengamalan nilai keislaman mendapat penghargaan dari guru berupa hadiahhadiah yang sederhana. Sedangkan untuk siswa yang memiliki pengamalan nilai keislaman buruk mendapatkan hukuman yang mendidik dan memperoleh pendekatan atau bimbingan khusus dari guru.

\section{Keberhasilan Internalisasi Pendidikan Agama Islam}

Proses internalisasi terjadi apabila individu menerima pengaruh dan bersedia bersikap menuruti pengaruh itu dikarenakan sikap tersebut sesuai dengan apa yang ia percayai dan sesuai dengan sistem yang dianutnya. Pembiasaan kesalehan yang dilakukan SD Muhammadiyah Kriyan Jepara membentuk siswa menjadi pelajar yang mampu memahami kebaikan dan keburukan. Para siswa melaksanakan upaya internalisasi itu karena memercayai dan menganutnya sebagai bekal membawa pada ketenteraman.

Dalam hal ini maka isi dan hakikat sikap yang diterima itu sendiri dianggap oleh individu sebagai memuaskan. Sikap demikian itulah yang biasanya tidak mudah untuk berubah selama sistem nilai yang ada dalam diri individu yang bersangkutan masih bertahan. Nilai-nilai keislaman yang terbiasa dipraktikkan oleh siswa SD Muhammadiyah Kriyan Jepara menunjukkan bahwa nilainilai keislaman itu tidak menimbulkan gejolak batin sehingga para siswa tetap merasa nikmat dalam menjalankannya. Upaya internalisasi demikian berhasil ditanamkan bukan karena penekanan yang keras, melainkan usaha pembiasaan nilai keislaman dilakukan sesering mungkin, baik di lingkungan sekolah maupun di rumah.

Teori pada bab II meyatakan bahwa kadang apa yang dialami oleh anak selalu berbeda dengan apa yang mereka inginkan. Nilai-nilai ajaran agama yang diharapkan dapat mengisi kekosongan batin mereka terkadang tidak sepenuhnya sesuai dengan harapan. SD Muhammadiyah Kriyan Jepara telah menyadari akan hal itu bahwa sikap kritis siswa terhadap lingkungan memang sejalan dengan perkembangan intelektual 
yang sedang dialami. Bila persoalan itu gagal diselesaikan maka anak cenderung untuk memilih jalan sendiri. Dalam situasi bingung dan konflik batin menyebabkan anak berada di persimpangan jalan lantaran sulit untuk menentukan pilihan yang tepat.

Dalam situasi yang demikian itu, maka peluang munculnya perilaku menyimpang terkuak lebar. Tidak jarang para remaja mengambil jalan pintas untuk mengatasi kemelut batin yang mereka alami itu akhirnya terjebak pada hal-hal negatif, yaitu tidak adanya sikap hormat dan sopan-santyun pada orang tua, mudah marah bahkan mengarah pada perilaku menyimpang seperti pergaulan bebas, narkoba, seks bebas.

Namun, apabila agama yang diterima anak dari orang tuanya di rumah sejalan dan serasi dengan apa yang diterima anak dari gurunya di sekolah, maka kehidupan beragama seorang anak akan berkembang baik. Oleh karenanya, pendidikan agama di sekolah juga dapat membantu perkembangan keberagamaan seorang anak. Pertumbuhan kesadaran moral, yang dihasilkan dari pendidikan agama, pada anak semakin meningkatkan kesadaran keingintahuan dan perhatiannya terhadap nasihat-nasihat agama dan kitab suci.

Olehkarenaitu,nilai-nilaiagamaIslam ditanamkan kepada para siswa dengan teori/ilmu yang dikuatkan dengan firman Allah SWT dan hadis Nabi Muhammad SAW maupun dengan keteladanan dari berbagai pihak (sekolah, keluarga dan masyarakat). Internalisasi agama Islam mula-mula berawal dari pemahaman dan akhirnya harus dilaksanakan pada tahap pengamalan sehari-hari dalam kehidupan nyata dengan memberi pengertian kepada siswa kemudian guru memberikan contoh konkret dalam bertutur, bersikap dan bertindak. Pemberian contoh dilakukan oleh semua unsur yang ada di sekolah sehingga mempengaruhi siswa untuk selalu menerapkan nilai-nilai keislaman dan adanya kesesuaian teori dan praktik nyata agar mampu memantapkan keyakinan siswa untuk mengamalkan kesalehan.

Internalisasi nilai-nilai pendidikan agama Islam di SD Muhammadiyah Kriyan Jepara memiliki tujuan-tujuan sebagai tolok ukur keberhasilan upaya internalisasi tersebut. Pertama, tujuan intelektual dan keilmuan; ialah mengembangkan kemampuan intelektual dan memiliki daya nalar dan sikap kritis yang tinggi. Kedua, tujuan moral; untuk menciptakan manusia yang memiliki akhlak yang luhur dan menjunjung nilai-nilai luhur kemanusiaan. Ketiga, tujuan agamis; ialah untuk memuat misi penegakkan agama untuk mempersiapkan kader-kader muslim agar siap mempertahankan negara sekaligus menyiarkan agama. Keempat, tujuan spiritual; untuk mengembangkan karakter kejiwaan yang Islami secara individu dan sosial. Kelima, tujuan jasmaniyah; untuk memperhatikan kesehatan dan penampilan jasmani manusia.

Tujuan intelektual dan keilmuan di SD Muhammadiyah Kriyan Jepara tampak berhasil dicapai dengan melihat pemahaman para siswa terhadap materi keagamaan yang didalami. Misalnya, siswa SD Muhammadiyah Kriyan Jepara tampak memuaskan dalam menjawab pertanyaan-pertanyaan seputar nilai keislaman yang penulis berikan kepadanya. Di samping itu intelektualitas keilmuan siswa SD Muhammadiyah Kriyan Jepara mewujud kesalehan ritual dan sosial pada tataran praksis seharihari. Dengan demikian tujuan moral dan spiritual menjadi tercapai karena mampu membentuk siswa menjadi pelajar yang saleh.

Tujuan agamis dan jasmaniyah juga tampak tercapai dengan melihat kesuksesan keagamaan dan kemuhammadiyah 
di SD Muhammadiyah Kriyan Jepara, seperti pembinaan siswa berprestasi, Darul Arqam, pembinaan siswa teladan, pengoptimalan ekstrakurikuler, pemantapan iman dan keislaman (PIK), Hizbul Wathan Camp, Gebyar Seni dan Out Bound. Tujuan pendidikan agama Islam yang telah diwujudkan itu, dapat ditarik kejelasan bahwa ruang lingkup pendidikan Islam tidak hanya dalam ranah keagamaan (ilmu-ilmu agama seperti akidah, ilmu Al-Qur'an, hadis, fikih dan lain-lain), tetapi juga dalam aspek yang lain dan lebih komprehensif sesuai dengan perkembangan dan kebutuhan manusia.

Abdullah Nashih 'Ulwan merumuskan ruang lingkup pendidikan agama Islam terdiri dari: pendidikan iman (akidah), pendidikan akhlak/budi pekerti, pendidikan fisik/ jasmani, pendidikan intelektual/ akal, pendidikan psikis/ jiwa, pendidikan sosial, dan pendidikan seksual yang kesemuanya satu kesatuan yang tidak terpisah-pisah (terpadu). Upaya internalisasi pendidikan agama Islam yang dilakukan SD Muhammadiyah Kriyan Jepara berdampak pada perkembangan siswa. Perkembangan itu berupa kematangan siswa dalam memahami dan mengamalkan nilai-nilai pendidikan agama Islam secara terpadu dan terbimbing.

Keberhasilan pada dasarnya adalah perubahan tingkah laku manusia untuk menjadi lebih baik. Adapun perubahan tersebut memunculkan beberapa ciri khusus, yaitu perubahan terjadi secara sadar, perubahan dalam belajar bersifat kontinu dan fugsional, perubahan dalam belajar bersifat positif dan aktif, perubahan dalam belajar bukan bersifat sementara, perubahan dalam belajar bertujuan atau terarah, perubahan mencakup seluruh aspek tingkah laku.

Keberhasilan internalisasi pendidikan agama Islam di SD Muhammadiyah Kriyan Jepara terhadap perkembangan anak adalah sebuah perubahan mental dan sikap yang muncul dari jiwa atau diri anak yang mengalami pembudayaan pedagogi positif dan aktif sehingga mental dan perilaku tersebut menjadi kuat dan membentuk pribadi muslim yang berkhlak mulia. Sebagian besar siswa mengatakan bahwa bentuk-bentuk perilaku yang mengandung nilai-nilai pendidikan agama Islam mewujud sebagai kesalehan ritual dan kesalehan sosial.

Kesalehan ritual dan sosial itu diantaranya adalah rajin salat lima waktu berjamaah di masjid, berdzikir dan berdo'a, belajar dengan sunguh-sungguh, berdoa dan berbakti kepada orang tua, berinteraksi dengan Al-Qur'an, berkata yang baik, rendah hati, menuntut ilmu, menghormati guru, menyayangi teman, tolong-menolong, menjaga kebersihan lingkungan.

Sebagian besar siswa memandang bahwa perilaku kesalehan yang diwujudkan dalam kehidupan sehari-hari dapat memengaruhi perkembangan dan kemajuan. Kesalehan ritual dan kesalehan sosial yang dilakukan adalah kewajiban seorang muslim dan kesadaran diri sendiri yang mendatangkan kemuliaan dan pahala dari Allah SWT. Namun, beberapa siswa melakukan kesalehan karena takut kepada orang lain, bukan karena Allah SWT. Beberapa siswa masih menunjukkan kesalehan hanya karena ingin mendapat hadiah dan pujian dari guru dan orang tuanya.

Sebagian besar siswa meyakini bahwa nilai-nilai pendidikan agama Islam sesuai dengan nilai-nilai kehidupan yang universal. Nilai-nilai pendidikan agama Islam sudah terbiasa diamalkan dalam kehidupan sehari-hari karena adanya keyakinan yang kuat dan pengetahuan yang tinggi bahwa perilaku kesalehan yang dilaksanakan mengandung kebenaran dan kebaikan.

Sebagian besar siswa mampu 
merasakan bahwa nilai-nilai pendidikan agama Islam yang dilakukan membawa kebahagiaan, kenyamanan, keamanan dan kedamaian bagi orang yang berada disekitarnya. Nilai-nilai pendidikan agama Islam yang diamalkan juga diyakini dapat memotivasi orang lain untuk berlomba-lomba dalam kesalehan ritual dan sosial.

Secara umum teori memandang bahwa keluarga merupakan sumber pendidikan nilai yang paling utama bagi anak-anak. Orang tua adalah guru pertama mereka dalam internalisasi pendidikan nilai-nilai keislaman. Mereka jugalah yang memberikan pengaruh paling lama terhadap perkembangan kesalehan anak-anak. Hubungan antar orang tua dan anak pun dipenuhi dengan berbagai perbedaan khusus dalam hal emosi, yang menyebabkan anak-anak merasakan dicintai dan dihargai atau sebaliknya. Akhirnya, para orang tua berada dalam posisi yang mengharuskan mereka untuk mengajarkan nilai sebagai bagian dari sebuah pandangan tentang dunia yang lebih besar yang menawarkan sebuah pandangan tentang arti hidup dan alasan-alasan utama sebagai pengantar sebuah kehidupan yang bermoral.

Di samping usaha yang disebarluaskan untuk membantu orang tua dan anak-anak, banyak hal yang dapat dilakukan sekolah untuk merekrut orang tua sebagai partner, baik tugas khusus maupun mengembangkan nilai keislaman dan karakter yang baik. Tantangan ini terdiri dari dua hal. Pertama, mendorong dan membantu orang tua untuk melaksanakan peran mereka sebagai pendidik utama kesalehan anak. Kedua, membuat orang tua mendukung sekolah dalam usahanya untuk mengajarkan nilai keislaman. Dengan demikian peranan keluarga, terutama orang tua, sangat berpengaruh dalam melakukan internalisasi pendidikan agama Islam.
Sebagian besar siswa mengatakan bahwa orang tua selalu menasihati untuk melaksanakan nilai-nilai pendidikan agama Islam. Orang tua merasa bersedih ketika melihat anak-anaknya enggan mengamalkan nilai-nilai keislaman, seperti enggan salat lima waktu, malas mengaji, malas belajar, bertengkar dengan kakak dan adik, berkata kasar dan kotor. Sebagian besar siswa meyakini bahwa peranan orang tua mampu mendorong siswa untuk terus melaksanakan nilainilai keislaman.

Dalam hal ini, orang tua menunjukkan peran sebagai agen internalisasi terhadap perkembangan anak. Sebagaimana Jacobs dan Fuller mengidentifikasi empat agen utama internalisasi, yaitu: (1) keluarga, (2) kelompok pertemanan, (3) lembaga pendidikan, dan (4) media massa. Para ahli menambahkan juga peran dan pengaruh dari lingkungan kerja. Namun demikian, Sekolah tampak belum memaksimalkan peran dari agen teman sebaya dan media massa.

Menurut Jacobs dan Fuller, teman sebaya justru seringkali berpengaruh terhadap perkembangan diri. Sedangkan menurut teori Ibn Miskawayh bahwa anak harus berteman dengan anak yang akhaknya baik agar anak dapat menerima perubahan-perubahan yang baik pula. Adapun juga media massa sangat perlu untuk dijadikan media internalisasi karena pesan-pesan yang disampaikan melalui media massa (televisi, radio, film, internet, surat kabar, makalah, buku, dan seterusnya) memberikan pengaruh bagi perkembangan diri seseorang, terutama anak-anak.

Beberapa hasil penelitian menyatakan bahwa sebagaian besar waktu anak-anak dan remaja dihabiskan untuk menonton televisi, bermain game online dan berkomunikasi melalui internet, seperti yahoo messenger, google talk, friendster, facebook, dan lain-lain. Oleh karena 
itu, penting bagi Sekolah untuk terus melakukan gerakan literasi, baik dengan media massa maupun dengan literasi digital.

\section{PENUTUP}

Berdasarkan pembahasan di atas dapat ditemukan simpulan sebagai berikut. Pertama, internalisasi nilainilai pendidikan agama Islam dengan penanaman teori/ilmu yang dikuatkan dengan firman Allah SWT dan hadis Nabi Muhammad saw. Kedua, internalisasi nilainilai pendidikan agama Islam dilakukan dengan kisah-kisah teladan dan hikmah kehidupan. Ketiga, internalisasi nilainilai pendidikan agama Islam dilakukan dengan pembelajaran materi agama dan umum yang saling terkoneksi melalui sinergitas kurikulum pendidikan nasional dan Kemuhammadiyahan. Selanjutnya keempat, internalisasinilai-nilaipendidikan agama Islam dilakukan melalui program pembiasaan intelektualitas, spiritualitas dan humanitas.

Dilihat dari sisi kesuksesan atau pencapaian, pembiasaan kesalehan di SD Muhammadiyah Kriyan Jepara berhasil membentuk siswa menjadi pelajar yang berkemajuan. Para siswa melaksanakan upaya internalisasi itu karena memercayai danmenganutnya sebagaibekalmembawa pada ketenangan pikir dan zikir. Upaya internalisasi berhasil dilakukan bukan karena penekanan pendidikan yang keras, melainkan usaha pembiasaan nilai-nilai pendidikan agama Islam yang humanis religius dan dilakukan sesering mungkin, baik di lingkungan sekolah maupun di rumah.

\section{DAFTAR PUSTAKA}

Achmadi. 2008. Ideologi Pendidikan Islam. Yogyakarta: Pustaka Belajar.

Daradjat, Zakiah. 2006. Ilmu Pendidikan Islam. Jakarta: PT. Bumi Aksara.

Dewantara, Ki Hajar. 1977. Pendidikan. Yogyakarta: Majelis Luhur Persatuan Tamansiswa.

Hasbullah. 2004. Kapita Selekta Pendidikan Islam. Jakarta: PT Raja Grafindo Persada.

Maa'rif, Ahmad Syafi'i. 1991. Pendidikan Islam di Indonesia Antara Cita dan Fakta. Yogyakarta: PT. Tiara Wacana.

Muzayyin, Arifin. 2003. Filsafat Pendidikan Islam. Jakarta: PT. Bumi Aksara.

Nata, Abudin. 2000. Ilmu Pendidikan Islam. Jakarta: PT Raja Grafindo Persada.

Suyudi, H.M. 2005. Pendidikan dalam Perspektif Al Qur'an: Integrasi Epistemologi Bayani, Burhani dan Irfani. Yogyakarta: Mikraj.

Tafsir, Ahmad. 2004. Ilmu Pendidikan dalam Perspektif Islam. Bandung: PT. Remaja Rosdakarya.

Undang-Undang RI No. 20 Tahun 2003. Sistem Pendidikan Nasional. Bandung: Citra Umbara. 